\title{
Criminal Responsibility for The Crime of Administrative, Financial Corruption and the Crime of Money Laundering
}

\author{
${ }^{1}$ Hasan Abdullah Saeed Saeed, 2 Haider Salahal-din Aref
}

${ }^{1,2}$ Faculty of Law \& International Relations, Soran University, Kurdistan Region of Iraq

\begin{abstract}
When we talk about economic crime, we mean the economic world as a special environment for the emergence and growth of crime. There is no doubt that the world of economy has developed with the development of civilization in the industrial renaissance, where the industrial inventions that brought the development of civilization to progress and growth and then reached the modern renaissance the revolution of technology, satellite and computer and its uses, and thus emerged other types of economic crimes that were not known before and do not necessarily accompanied by violence, but it appeared that the perpetrators of these crimes of different quality destroy the theory of "Lombroso" we have seen criminals of another model, the most luxurious of white collar and smarter than the most serious criminals we have read or encountered in our lives. Wars and crises have helped to develop the economic penal law, especially the First World War.

During this war, some of the activities directed against the system of food grain supply and the crisis known by the world beginning in (1929) has also recorded the important impact on the development of economic sanctions law, economic sanctions law by nature aims to protect economic policy and the appearance of this policy legislation economic development, which is issued by the state. Therefore, the definition of economic law is one of the most important and necessary issues to define the economic penal law. Perhaps the most prominent field in this development is the field of economic relations. The law and the economy are two types of law of the society and the modern state can no longer overlook the interference in the economy even if economic freedom has been inspired as a fundamental principle and the relationship of economic crime to economic science. Economic crime is an integral part of the economy and therefore economic irregularities are not considered a form of deviation but are rooted in economics himself and the market is considered the primary responsibility for illegal actions and the term economic law can be raised in all societies, regardless of the degree of development.

Regardless of how the organization of its economic activity because it is linked to a normal relationship is the relationship of law to the economy, a relationship of cooperation between two branches of social sciences (law in the service of economy) and (economy in the service of law) for example, require legal regulation or the inevitable outcome of the presence of monopolistic centers and consequently the retreat of free competition and economy is in the service of the law when it helps to understand the forensic systems and to clarify their reality and to clarify the change in the application may reach to the point of emptying it of its content, despite the fact that its text and its external frame remain stable and stable.

This study is intended to examine the most important and most serious types of economic crimes such as administrative and financial corruption and money laundering. These crimes constitute a danger to national and international security through the alliances of organized crime gangs and terrorist gangs.
\end{abstract}

Keywords: Economic Crime, Economic Development, Administrative Corruption, Money Laundering.

\section{Introduction}

In the midst of the concern of some countries of the world to seek to consolidate the foundations of the new financial system, through the imposition of the rules of political, economic and social aims to free the movement of individuals and goods in light of the tremendous progress that exceeded the previous centuries in conjunction with the phenomenon of globalization in which the world has become a vast village Are linked closely through the communications and information revolution.

This was accompanied by several phenomena, including the phenomenon of administrative and financial corruption leading to the crime of money laundering in various aspects of life in different countries of the world. Because of the importance of these two topics as they relate to illicit activity and the organized activities of 
organized criminal groups, both domestic and international, that concern various States, international organizations and bodies in circumstances where territorial boundaries no longer constitute an obstacle or obstacle to the exercise of this illicit activity, economic corruption is one of the most important economic phenomena that have negative effects on any economy plagued by this scourge, and its types and causes.

However, it can be said that weak government control and the prevalence of bad social habits is one of the most important reasons leading to it, especially if it is linked to major objects whose interests are linked to the interests of senior politicians.

Iraq has witnessed waves of economic corruption, which emerged remarkably in the eighties of the last century and intensified in the nineties because of the economic sanctions imposed on Iraq, which decreased the levels of living citizens and employees very large forced some to resort to the practice of corruption for Cover the normal expenses of their lives.

After (2003), corruption became a normal phenomenon practiced by the highest levels in the government authorities and political parties. There were major mafias dealing with corruption, based on the power of the authorities, parties, lack of rule of law and weak roles exercised by the supervisory bodies such as the "Financial Supervision Bureau" or the "Integrity Commission" and the "Offices of the Public Inspectors". Although successive governments have declared their fight against corruption, some have been mere declarations, while others have collided with the power of the spoilers and their power based on the strength of their parties and their association with a powerful series of corrupters who cover each other. The current government is fighting corruption to eliminate it, may be prolonged.

The impact of this phenomenon on the international community necessitated a change in the forms of crime, in which the characteristics of both domestic and international crime were combined with a new phenomenon called money laundering or money laundering, in which relations were intertwined and criminal groups, both national and international, And crime scene for these criminal groups are markets for their activities.

That the growing need to confront organized international crime and the associated crime of moneylaundering confirms the importance of every work that deals with the analysis, analysis and legal means available to control this type of criminal pattern.

\subsection{The Problem of the Study}

The economic corruption leads to waste and a large loss of economic resources, and weaken the possibility of optimal allocation, which leads to the disruption of economic development plans and the loss of opportunities for economic growth, as well as the spread of other types of economic crimes, which of The most important of which is the crime of money laundering, so that these two crimes are linked in backward economic systems, with no real will to confront these crimes.

\subsection{The Importance of the Study}

The importance of the study is reflected in the fact that it deals with two serious negative economic phenomena that have a correlated relationship that left their destructive effects on the economy and that all countries must fight against these phenomena and dispose of them and exploit their resources accordingly.

\subsection{Objectives of the Study}

The study aims to study the crimes of administrative and financial corruption as well as the crime of money laundering, and identify the causes and develop appropriate solutions to eliminate them.

\subsection{Structure of the Study}

Through studying the problem of the study and the 
objectives to be achieved, the study has been identified with two main areas:

The first topic dealt with economic crime and administrative and financial corruption and the crime of money laundering.

The second topic: the responsibility of the criminal bank for the crime of money laundering.

\section{Economic Crime: Administrative and Financial} Corruption And Money Laundering

Economic crimes are among the most important indicators that create a kind of heterogeneity in the social system, by hindering the course of development at all levels, economic, social or cultural, in the light of globalization, which made the economies of countries a free economy, causing the liberalization of trade and the opening of borders and the opening up of markets on different capital, coincided with a scientific leap that has developed the field of information and communication technology.

As a result of these changes, an environment has emerged for the growth and growth of economic and financial crime at the international and national levels. These changes have led to the emergence of new or unknown crimes, as well as the development of some classic economic crimes. To modern methods and technologies based on technology that has been difficult to fight and detect and follow the criminals on them.

Economic and financial crime may have benefited from economic globalization more than those who fought against this phenomenon. Economic and financial institutions have become dominated by the financial mafia specialized in drug trafficking and smuggling of goods, counterfeiting of all kinds, money laundering and fraud in goods and materials as well as tax evasion and fraud, in addition to manipulating the prices of stocks and bonds in global financial markets.

\subsection{Economic Crime}

The definition of economic crime is characterized by a multiplicity of legislations dealing with economic and financial crimes through independent laws or those legislations which they have dealt with in texts scattered in different laws.

"Nivoda" defines it as a crime that directly or indirectly harms or threatens the interests of the national economy or the economic system itself, so that the criminal law contains its elements. ${ }^{(i)}$

"Martinez" defines them as "offenses committed by persons of a high economic standard, who, through the exercise of their professional activities, breach the trust of social relations, damage or endanger the economic order". (ii)

As well as any act that would harm public funds and the processes of production, distribution, circulation and consumption of goods and services, and punishable by laws aimed at protecting public funds, the national economy and economic policy. (iii)

One of these definitions is that economic crime is those illegal behaviors carried out by individuals who are outside the laws that control the economic side of the society and obstruct the course of economic development.

\subsection{Administrative and Financial Corruption}

Among the most important crimes that impede the economic development of any society, administrative and financial corruption have multiple concepts and definitions depending on the direction it is interpreted, including the definition of the World Bank, which pointed out that "administrative and financial corruption" is: "abuse of public authority to gain corruption occurs when a public official accepts, requests, extorts or bribes to facilitate a contract or a public competition, and when brokers or agents of private companies or businesses offer bribes to benefit from public policies or procedures to overcome 
competitors and make profits outside the framework of laws, as well be the corruption that gets aviate coordination to exploit public office without resorting to bribery by appointing relatives or theft of state funds". (iv) The Encyclopedia of Social Sciences has known corruption as "misuse of public influence for private gain". It also defined it as "out of law and the general social order and non-adherence to them for the political, social or economic interests of an individual or group. ${ }^{(v)}$ It is also known as stored behavior practiced by some public officials within and outside the administrative system that leads to the deviation of that organization from its objectives in favor of other objectives.(vi)

\subsubsection{Types of Administrative and Financial}

\section{Corruption}

Administrative and financial corruption is divided into two parts in terms of size and prevalence.

- First: Size: in terms of:

- Small Size: It is in the lower levels of management and it appears unilaterally and it is by accepting bribes and blackmail in order to obtain them in return for performing a service or expediting the completion thereof.

- Large Size: We find it in the senior officials and officials in the state apparatus, so that they receive huge amounts in return for granting access to companies or the establishment of an economic project and this type is the most harmful and deadly.

- In Terms of Proliferation: The division of corruption is divided into two categories:

- Local corruption: It is spread exclusively in one society or country and in its administrative institutions.

- International Corruption: Corruption that transcends the boundaries of one state or society to another, such as transnational corporations, and may exceed that of another continent.(vii)

\subsubsection{Reasons of Administrative and Financial Corruption}

The reasons for administrative corruption are summarized in the following:

\subsubsection{Economic Reasons}

Economic causes are one of the main causes of administrative and financial corruption. Corruption usually occurs when there is no sense of supervision and accountability. When a public institution employee monopolizes the distribution of benefits to be used for special reasons,

- The low level of income of the economic perpetrator compared with the level of inflation or prices traded locally, which makes real income so low that it is unable to satisfy the necessary needs, which makes it resort to bribery, embezzlement, drug trafficking and others.

- For unequal distribution of wealth and income among members of society.

- Openness to foreign companies and work with them on a large scale.

- The high degree of international competition between the giants leads to the spread of crimes of economic obsession, especially in the field of industry policies relating to taxes and fees and collection and impact on income.

\subsubsection{Social Reasons}

Social causes leading to administrative and financial corruption are one of the most important indicators in measuring the prevalence of this corruption, and can be summarized as follows:

- Contribution of some social systems inherited in developing countries in the presence of doors to the occurrence of corruption, especially in the administrative system of the state, so spread habits 
of giving valuable gifts to senior officials to obtain illegal things.

- Employment of tribal affiliations or knowledge through administrative recruitment or award of contracts.

- Stop sighting or detecting corruption, which leads to the continuation of the occurrence and the difficulty of combating it.

\subsubsection{Political Reasons}

The political causes of administrative and financial corruption are among the most influential indicators because of the existence of the executive authority. Among these reasons are the following:

- The weakness of the political institutions and the inefficiency of their executive and supervisory bodies. The stronger the state and its powerful apparatuses, the less corruption is eliminated.

- The close relationship between internal political systems and international sources of corruption.

- The lack of clarity of instructions and their issuance without the existence of evidence easy to apply, which creates confusion in individuals, forcing them to personal diligence and then the possibility of deviation and break the spirit of instruction.

- Coupling political power with wealth and the intertwining of interests and benefits between politicians, businessmen and businessmen.

\subsubsection{Administrative Reasons}

Management is the environment in which corruption is practiced both in terms of structure or in terms of organization and the administrative causes of corruption are the most important:

- Poor control through the failure of the SAIs to perform the tasks entrusted to them.

- The existence of organizational structures old or inappropriate to the nature of work and the lack of distribution of competencies, responsibilities and powers in a scientific manner, and amplify the device unemployed, all lead to the inability of the administrative system to keep pace with the needs of the public and deviate from the organizational structure, forcing individuals to meet difficulties to satisfy Motivated and satisfied desires to pressure individuals and seduce them to follow behavior away from the rules of work and systems.(viii)

\subsubsection{The Manifestations of Administrative Corruption}

Administrative and financial corruption is manifested in several aspects, the most important of which are:

\subsubsection{Bribery}

Is one of the most serious crimes and one of the worst forms of administrative corruption is the trafficking or exploitation of a public official or a public official by requesting or receiving a gift or a promise to perform or refrain from performing a job or breach of his duties.

\subsubsection{Embezzlement}

It is a betrayal of the public servant to the loyalty of the advocate, the cash or in-kind in his custody, as well as the public trust entrusted to him because of his functional authority.

\subsubsection{Commissions vs. Transactions}

A commission is a sum of money representing a percentage of the value of a contract or transaction that the employee receives by signing it on behalf of his organization. The second party is a contractor, a supplier, a source or a person under their control.

\subsubsection{Tax Evasion}

which takes two forms, the first form is the exploitation of taxpayers for legal changes and resort to tricks that enable them to get rid of taxes due without putting themselves in front of legal accountability, the second form is illegal tax evasion practices that violate the subject Taxation of legal provisions by means of fraud, forgery and bribery to escape the taxes due.

\subsubsection{Counterfeiting and Counterfeiting}


It is known that every coin making is a tradition of a correct currency, and every manipulation of the value of a correct currency, as well as any promotion or entry from outside of the counterfeit currency if these things are done with the intention of putting the counterfeit currency in circulation and fraud.

\subsubsection{Extortion}

Another manifestation of administrative corruption practiced by some employees, especially those working in the security or sovereign agencies responsible for the protection and dissemination of security and tranquility or control of economic activities or other investigative, disciplinary and punitive devices such as prisons, courts or by committees Discipline, checkpoints and control.

\subsubsection{Bias and Favoritism}

It is a method is through the location of the individual and occupies a social position, granting opportunities and privileges to relatives and friends at the expense of people with competence and merit.

\subsubsection{Interventions}

It is the introduction of a third party with social potential to influence the outcome of social relations between two parties to a social relationship in a particular situation. It is the intercession of officials or guardians to raise grievances, to obtain a right, or to bring benefit to others.

\subsection{What Is the Crime of Money Laundering?}

Money laundering is one of the most serious crimes that threaten global security, as well as its devastating economic and social repercussions.

This phenomenon is one of the global phenomena that accompany its emergence with two global phenomena: scientific and technical development, globalization resulting in the globalization of banking systems, which increased interaction between States and facilitated the transfer of capital between them allowed organized criminal gangs to carry out their activities through illegal fund-raising and later to appear as if they were generated from a legitimate source by changing circumstances as there was no uniform legal regulation at the regional or international level to deal with them. The problem of money laundering has become a sophisticated phenomenon, in a coherent and effective manner, of the current problems affecting the security of all countries, which are equal in developed countries or developing countries. The phenomenon of money laundering is also a form of economic crime.

Although the latter is more extensive and comprehensive and is one of the crimes of assault on the funds that lie at the heart of the special section of the Penal Code, falls within the scope and where they are crimes that may transcend the borders of a single State, also criminal international law.

Money laundering is a crime related to trade law and the global trade movement, so banks have limited obligations to ensure the fight against money laundering. Therefore, the compatibility between criminal and economic policy is a natural prelude to achieving positive results. Combating crimes with an economic dimension the phenomenon of money laundering is one of the new criminal images that are beyond the borders, where they are becoming increasingly dangerous, and which must be dealt with by both economic and criminal legislation.

One State, which is transnational in nature, requires effective cooperation to overcome the negative effects of money-laundering operations, as a phenomenon which, in its general effect, transcends its own national borders, exceeds all the limits of past and present time and extends its influence To the future, it is no longer limited to domestic criminality, but extended to the international organized crime, which has become a source of alarm for the various countries of the world. This has led to the growth of the international 
community's will to combat this crime and reduce its seriousness. To States to fight Money laundering in the framework of the United Nations in order to assist States and numerous conferences, meetings and committee's problem globally is not capable of combating money laundering and pressure in the event of its failure to cooperate. This international anti-money laundering activity is caused by the large amount of money that is washed annually.

This money flows into the accounts of gangs, international terrorist organizations, and political organizations, religious and religious, with different tendencies that contribute to controlling some of the world's political systems. It is easy to move capital across countries, which have been illegally obtained and recycled in legitimate investment areas and channels that appear to have been generated from a legitimate source.

The international community, in the framework of international organizations and bodies, and in the form of international or multilateral agreements, recognized the need to confront this crime, which is based on basic and complementary themes, whether it is objective or criminal, and seeks to strengthen the role of the financial system and increase international cooperation. Therefore, there was a need for legislation and laws in each country to prevent, punish or complicate or facilitate the process of money laundering, Economic, social and political world.

Since the crime of money laundering is an economic crime, confronting the criminal law of this phenomenon will be more effective in that it addresses the basic aspects of the well-being of social life by protecting the public interest by balancing rights, freedoms and duties with the criminal law's ability to achieve deterrence Both public and private, to those who commit or attempt to commit a crime. It is striking that the general theory of crime has failed to absorb many of the new criminal phenomena that are the result of technical progress. The crime of money laundering is one of the examples of these and complicates the economic and social activities of the individual in general phenomena.

\subsubsection{Definition of Money Laundering}

The term Money Laundering was first used in English (1973), a translation adopted by the United Nations in its documents. The term "money laundering" means any act or project aimed at concealing or disguising the nature of proceeds Derived from illicit activities so that they appear to have been derived from legitimate sources so that they may then be used for legitimate activities within or outside the State.(ix)

"The European Commission for the Prevention of Money Laundering (1990)" defined as "the process of transferring funds obtained from criminal activities with the aim of concealing or denying the illegal and prohibited source of such funds or assisting any person who committed an offense by evading legal responsibility to retain the proceeds of this offense". ${ }^{(x)}$ It can also be defined as a crime that cleanses dirty money from illegitimacy, and dirty money is any amount of money or all that can be assessed with money received by the person in violation of the provisions of the law.

The jurists agree on the definition of dirty money laundering as: "any act, deferral, transfer or alteration of the nature, property, quality or identity of funds obtained from criminal or illegal activities or acts, in order to cover, camouflage and conceal the original source Legal basis for such funds, in order to ultimately emerge as clean funds and of sound and legitimate assets, while originally they are not". (xi)

All of these definitions can be summed up by the fact that money-laundering is a process aimed at concealing the true source of illicit income and attempting to 
legitimize it and show it as if it were the result of legitimate activities.

\subsubsection{Types of Money Laundering}

The crime of money laundering different and multiple images can be limited to the following:(xii)

\subsubsection{Smuggling and Exchange of Currencies}

This process can be described by placing suspicious funds in a current account in a bank and then transferred or transferred to another account through multiple movements and intertwined so that it is difficult to distinguish between these accounts between the clean and other funds The financial and monetary policies of developing countries, which wish to encourage foreign investment to improve the situation of national economies, sometimes require them to take legislative and economic measures to cope with the global economic situation. The transfer of funds and transfer without obtaining prior approvals from relevant government agencies, including central banks, in addition to traditional methods such as transport by trucks across borders, aircraft, ships and others.

\subsubsection{The use of Fictitious Companies}

Companies are sometimes established legally, but they do not actually practice any actual activities or projects. Accounts are opened on behalf of the company internally and externally and thus become a legal haven for money laundering attempts. These companies are effectively deployed in countries that lack To the control of the Court or characterized by a system of secrecy of banking operations and stability of the monetary and political environment or their occurrence on the lines of international trade and ease of entry and exit and the ease of procedures in the establishment or purchase of companies.

2.3.2.3 Phantom Transactions and the Role of Brokerage and Gambling and the Purchase of Physical Assets
Phantom transactions are used as one of the traditional methods of money laundering. This is achieved through the use of international prices, inflating real numbers and using false invoices, all for the purpose of justifying the money obtained as the price of such delusional transactions or the large profits that may give rise to certain uncertainties.

The use of the means of buying physical assets such as cars and precious metals for those operations through resale, therefore, the role of brokerage can be used by financing large amounts of money to brokers to buy shares, bonds or real estate by their names or other names At an inflated price, especially in real estate.

The gambling role can also be used for money laundering by buying casino casinos, and then asking for the money to be handed over to another person in cash or by opening an account as the latter has won and so it is easy to claim that the latter had earned them from gambling.

\subsubsection{Stages of Money Laundering Through Banks}

The money obtained from illegal sources in three stages for the purpose of washing and gives the legitimate source of circulation as if the funds of legitimacy as follows:(xiii)

\subsubsection{Deposit or Replacement}

This is the stage of the acquisition of illegal funds in one of the previously mentioned images. This phase means the disposal of suspicious funds by depositing them in banks and financial institutions, buying real estate, shares, bonds or traveler's checks and participating in investment projects. And it is a period of stagnation of money where it is placed in a specific place for a period of time with a view to a period of forgetting the source of the illegal and those shares have been sold and then transfer funds beyond the borders of the country in which the deposit is usually resort to Securities Traders or payment orders by writing cash on those papers and 
facilitating the movement of those securities or deposit them

This is considered to be the most difficult and difficult stage, considering that money laundering is a party to the equation, therefore, countries whose economic system is open and does not criminalize operations Money laundering.

\subsubsection{The Stage of Coverage}

This stage is carried out after the entry of funds into the banking sector, in order to separate these funds from their original illegal activities, and this is done through a series of complex and sequential operations, all in order to hide the sources of these funds, As the stage where the disclosure of the sources of these funds more difficult, through the use of securities that are easy to transfer checks, shares, bonds and payments, through the account, where the foreign bank to open an account in a local bank and the workers of the foreign bank Withdrawal and deposit In this account to manage their suspicious activities and buy high-value capital, resold and technological advances, the money-lenders have resorted to modern electronic means to camouflage their activities in order to erase the effects of crime, because they are fast and long distances and the ability to hide the name And to eliminate any accounting implications in this context.

\subsubsection{The Stage of Integration}

This is the final stage in the money laundering process, or the last stage of money laundering, in which the illegal money is integrated into the legitimate funds and enters into the national economy so that it is difficult to distinguish between the legitimate and the illegal money. Is done openly, unlike the previous two stages, and thus takes a legitimate legal appearance.

\subsubsection{Modern Methods of Money Laundering}

Money Laundering operations have become more technical, more complex, more difficult, and more impractical to detect. Some of the most modern methods in the global and national arena are as follows:(xiv)

\subsection{Money Laundering through Electronic Banks:}

This is the most common method in the field of money laundering either in the traditional or electronic way. It starts according to the usual stages of money laundering. The deposit level assumes the opening of an account and the opening of an electronic account. By entering the website, fill out a form whose bank form is selectable and can be signed electronically, in which the customer chooses the real or fake names or even symbols, whether numeric or character, and the account opening process ends at this time. The limit is not limited to open only one account, but have multiple bank accounts in different banks and different countries.

E-filing features a range of features such as encryption to ensure the confidentiality of deposits and the subsequent use of computers and the use of smart cards, followed by the process of investment by the bank to contribute to money laundering indirectly without the fact that the source is that Banks According to the nature of their activity, the depositors' funds are invested in various projects that generate profits through which they can lead to the clients' agreed benefits. Therefore, the illegal funds mix with depositors' funds in general. The money is used as a unit in the investment However, the depositor of the illicit funds may invest in accordance with the regulations set by the bank by applying for loans to guarantee these deposits, which is a matter for the bank to earn a difference between the interest of the deposit and the interest of the borrowing.

It is not necessary, of course, to borrow from the same bank in which the money was deposited. Rather, the loan may be requested from another bank to guarantee the deposit. This bank may be in a country other than the depositary country and the borrowed funds are clean funds through which it can participate. Projects or 
purchases of property appear to be perfectly legitimate. The most recent process offered by e-banks to money launderers is the electronic withdrawal process through which the account holder can obtain from the depositing bank a magnetic card that enables him to withdraw money from anywhere In the world wa Which happens because the money launderer if he puts his money in local currencies that do not have an appropriate exchange rate compared to foreign currencies with a strong cover such as the dollar and the euro, for example, it resorts to countries that deal with these currencies and withdraw funds electronically out of bounds without risk .

\subsection{Money Laundering through Electronic} Commerce

According to the development of information and communication technology, the phenomenon of ecommerce has recently spread over the Internet. The presence of parties to the contract is not required in the face of the contract and the obligations of the contract are not required in the same place, In the Civil Code, the “United Nations Commission on International Trade Law, UNCITRAL" approved a model for a unified electronic commerce bill (16 December 1996), although the Convention did not define the concept of ecommerce, Information between two devices for the computer according to certain rules agreed both for presentation, application, or contract execution.

\subsection{Applications of Criminal Liability For Economic Crime}

Liability generally means that a person has a certain legal obligation or penalty as a result of his or her act or conduct, which is regulated by law and this responsibility is either civil and is the obligation of the individual to bear the obligation under the contract to which he is a party, or an obligation to compensate for the damage caused by the act (tort).
This criminal responsibility is the person's ability to bear the criminal penalty stipulated in the law as a result of the offense committed by the law. Therefore, it can be said that the appointment of the person who is criminally responsible for a specific offense includes the application of the rules of attribution, To say that the act was made by that person by proving the direct link between the actor's activity and the crime committed (causation).

This also includes the application of the rules of eligibility, which means the eligibility of the person to whom the crime is attributed to bear criminal responsibility for the criminal offense and the criminal penalty imposed by law on the perpetrator of the criminal act. $(x v)$

Under the crime of money-laundering, the criminal responsibility for this offense is different depending on the person who committed it. The offense may be committed by the bank as a legal person with the legal capacity to assume criminal responsibility when the money laundering activities are carried out through the bank. Who carries out money-laundering activity through the bank or financial institution in which he works for his personal benefit. The client may commit the money-laundering activity. He assumes the criminal responsibility for this crime. The crime may be committed by all or some of them. Who commits the crime of criminal responsibility, and this is what will be addressed in this chapter specifically. (xvi)

\section{Section Tow: The Responsibility Of The Criminal Bank For The Crime Of Money Laundering}

The book dealt with the criminal law and the subject of criminal accountability of the criminal person with extensive research and headed the majority of opinions to give priority to the criminal legal accountability to other ideas, specifically under the Economic Penal Code for the success of economic policy. (xvii) 
These are based on a set of practical considerations in addition to the legal arguments, as follows:(xviii)

\subsection{The Practical Considerations And Legal} Arguments For The Legal Person's Question Of Economic Crimes

\subsubsection{Practical Considerations}

Most economic crimes are committed for the purpose of earning, and this gain is often achieved for the benefit of the group of persons whose money is in total the financial liability of that legal person. Therefore, it can be said that the penalty would not work Its impact on the natural person who committed the crime from a material point of view, its financial value often does not allow coverage of the damage and will not prevent its punishment from repeating the crime. This is not the case if the penalty was directed to the legal person and its effects were incurred in his financial and business activities.

\subsubsection{Legal Arguments}

It can be summarized as follows:

- The moral pillar greatly weakens economic crimes and therefore there will be no difficulty in assigning the mistake to the moral person.

- The law concerns the legal person with penalties of a special nature that are appropriate to the nature of the legal person as penalties (fines, confiscation and closure). Many of the sanctions in the Economic Penal Code were not aimed at atonement and correction, Crime again in the future.

- As long as the inducement of sanctions is merely precautionary and precautionary measures such as protective measures, such measures may be signed merely to invoke danger without requiring error or discrimination.

\subsection{Legal Treatment Of Criminal Bank Liability}

Criminal jurisprudence differed in determining the legal nature or legal basis of the responsibility of the criminal bank as a juridical person, and a section was founded on the basis of responsibility for the act of others. (xix)

Others consider it to be a material, objective or absolute responsibility, and there are other opinions that adapt this responsibility as a collective responsibility of the members of the moral person and make it another part of personal responsibility to which the general principles of the Penal Code apply, namely, A person who considers that the determination of the criminal responsibility of the legal person is justified by the necessities of achieving the same interest that justified the existence of the legal person in accordance with certain controls. $(\mathrm{xx})$

It is the philosophy and ideology of the political system prevailing in a given society that determines the establishment of such a responsibility in that country, as well as the notion that the interest of that juridical person has been justified and the recognition of legal will is the most acceptable idea of determining the legal basis for such responsibility.

In most cases, most criminal legislation of most states has recognized the criminal responsibility of moral persons. This is what the Iraqi legislator went through under specifically Article (80) of “Iraqi Penal Code No. (111) of (1969)".

The Iraqi legislator also addressed this responsibility within other laws such as the Unlawful Mediation "Act No. (8) Of (1976)" and the "Law of Cooperation No. (202) Of (1971)", which recognized the possibility of criminal accountability of a criminal person. ${ }^{(x x i)}$

The Bank shall be asked as a legal person if the mistake is made by its legal representative or by an agent thereof, (xxii) and the error shall also be issued by the Bank itself in the event that the mistake was issued by the Director of the Bank on the basis of the rule of responsibility of the person responsible for subsidiary acts which fall from the subsidiary in the performance of his or her 
functions, which is within the jurisdiction of the director. In most criminal legislation of most States, the judiciary has gone on to expand the accountability of the Bank for the actions of its subordinates, which are in direct contact with their functions. The Bank is criminally responsible for the actions of its affiliates, Their positions on the This abuse is not visible to customers and can justify the expansion of the Bank's accountability to the desire to protect the interests of the public which often depends on the situation phenomenon.(xxiii)

If the banks have issued (illegal practices), (xxiv) the criminal bank's responsibility for these practices has resulted in the bank having the penalties provided for in the law. When there is no law or regulation subject to review by the bank, Activity such as illegal practices, which entail the criminal accountability of the Bank.

The principle of determining the criminal responsibility of the bank and financial institutions for the crime of money laundering has become more stable in all the national criminal legislation that dealt with this crime, specifically in the process of this principle of international law, through the provision of this principle in the recommendations (fortieth) "Financial Action Committee (1990)" (xxv) under "Development of National Legal Systems" to recognize "The Principle Of The Moral Character Of Banks And Financial Institutions Operating In The Area Of Securities". These recommendations expressly stated the principle of "the responsibility as stated in recommendation seven "(although it is possible that companies themselves should be subject to criminal liability and not only to their employees". (xxvi)

In his report on this responsibility, the international legislator sought to protect society and its public interests. It is likely that the bank or financial institution will be held criminally responsible for the crime of money laundering to breach its obligation to prevent the occurrence of this crime and this is the result of the violation of the legal provisions that have led them to a number of obligations that prevent the crime of money laundering, which in turn requires accountability (B) The bank shall be liable for the acts of its representatives and shall be punished by being a legal person who is entitled to criminal liability. (xxvii)

And the responsibility of the bank for the work of its representatives is an exception to the original provided in certain cases and therefore cannot be measured by the original in the criminal responsibility is personal and punishment is not expected only to the person who committed the same crime, whether an actor or a partner and this exception may be provided in the law Penalties or any other punitive law, the bank's responsibility for the money-laundering offense here is a type of liability assumed by law. This legal presumption is not a conclusive presumption but can be proven contrary when it is found that the bank was unable to prevent the laundering offense because of force majeure, for example the question is whether the bank can adhere to some of the banking principles stipulated in the law, especially the principle of banking secrecy, (xxviii) to avoid criminal responsibility for the crime of money laundering.

The laws of some states provide for the competent authorities to be informed of important deposits, for example to report suspicious transactions. This is what the American legislator has done. Since 1970, financial institutions have been required to inform the authorities of every financial transaction exceeding US \$10,000. Money launderers can evade these measures by dividing their creations into segments of low monetary value or by making deposits by companies whose principal owners cannot be identified. On the other hand, if banks tighten their bank account opening operations for unknown customers Of them or not (Such as cutting operations on the Fund, issuing remittances to non- 
customers, automated bank windows), all of which help to convert weak currencies and collect them for a stronger future. And then the success of illegal money laundering without disclosure from banks, and through the above can you say that the principle of bank secrecy is the obligation placed on banks and not to interfere in the affairs of the client financial,(xxix) which is that when the customer enters with the bank in a financial relationship, it is certain that the bank does not do the disclosure in its own affairs and non-intervention? However, the principle of bank secrecy and the obligation of non-intervention is not absolute. Criminal jurisprudence cited an exception to this principle and their argument that when a bank opens an account to one of its clients, it provides it with a weapon that can be very dangerous. $(\mathrm{x} x \mathrm{x})$

The judiciary tends to recognize the banking institutions with a great deal of control and scrutiny in the process of opening the bank account, and that any lack of such checks and checks by the banking institution expose them to legal accountability.

In recent years, jurisprudence and criminal justice have tended to expand from this field of control to extending beyond the opening of the account to an operational period, where the obligation of non-intervention is wasted in order to be vigilant and vigilant in order to control irregularities or indicators that draw attention, Clear and definite discipline or movement of funds to detect fraud or illegal movement, and so it can be said that the duty to report and disposal of banking secrecy finds its corner in the duty of caution and vigilance. In this context, recommendation (16) of the "Financial Action Task Force, FATF" calls for the need to enact legal provisions that protect banking institutions and their employees from criminal or civil liability resulting from violating the principle of bank secrecy provided for in any law or decision that has the force of law Whether administratively or administratively, if this principle is discharged in good faith and in the effort to detect suspicious transactions. ${ }^{(x \times x i)}$

Most of the legislations dealing with the crime of money laundering have tended to expose polluted funds and waste banking secrecy pursuant to recommendation "No. (16) of the "Financial Action Task Force, FATF" and make it an exception to the principle of banking secrecy, (xxxii) as did the French legislator in "Act No. (90/614) Of (1990)" and the Belgian legislator in the "Act of (17 July 1990)" on combating money-laundering and the American legislator in the "US Anti-Money Laundering Act (1994)", which called on Switzerland to reduce the principle of bank secrecy as this principle began in Switzerland retreats in the face of suspicious transactions related to money laundering crimes and Switzerland has increased the volume of international cooperation with foreign governments and help these governments in the prosecution of some Moneylaundering offenses, particularly those of a political nature, may be Suu's wish Secretly in maintaining the reputation of the banks of money laundering crimes is the one who invited her to it.(xxxiii)

\section{Conclusions}

- Economic corruption has been a phenomenon in most economies, especially developing economies, which have had a major impact on economic performance through the waste of economic resources and the misallocation of economic resources.

- Types of economic corruption vary according to the diversity of its causes. Therefore, the ways of dealing with them vary according to the nature and type of corruption and its power and the ability of the government to impose its authority to deal with this corruption. 
- The weakness of the supervisory and judicial apparatus and the non-unification of its basic functions and complacency with the defaulters and the facilitators cause the spread of the phenomenon of corruption and the multiplicity of these organs and lack of adequate coordination among them was one of the reasons for not addressing the root of corruption, especially that some of them subject to political and partisan influences.

- The widespread use of corruption, of course, leads to a reduction in revenues of the public treasury and deprives them of the resources needed by the state to spend on and develop public services.

- Corruption in the field of implementation of projects and contractors gives way to the implementers of these projects to manipulate specifications, which negatively affects the quality of projects in terms of technical as well as high costs.

- Corruption affects the distributive justice of income and wealth in favor of the most powerful in society (and those who monopolize power) or those close to it, thereby increasing class differences in income and wealth, including negative effects on the social fabric and political stability.

- Corruption in Iraq is today the biggest and only factor that undermines the credibility of the government and is a threat to national security. While the government is working to attract foreign investment to the country and reconstruction of infrastructure, foreign investors are forced to pay money to facilitate access to the required services, which are supposed to be part of the work of the normal government administration, which prompts many of them to refrain from investing in Iraq, Hence, administrative and financial corruption would impede the development process and hamper the country's efforts to enter the business community in the world as a player on an equal footing with others.

- With regard to the definition of the crime of money laundering, it emerged through the research that there are definitions of crime in the framework of jurisprudence and that all the legal legislation that dealt with this crime took upon itself to develop a definition of the crime under discussion whether internal legislation, National or international. All of these definitions included one substance and differed in the scope of the definition. This essence is an attempt to hide or obliterate the illegitimate nature of the source of the dirty funds.

- With regard to the characteristics of the crime of money-laundering, it has been found that crime has characteristics that distinguish it from other criminal phenomena. In the forefront of these characteristics is an organized international economic crime, the perpetrators of globalization found a great opportunity to expand their criminal activity, In a manner that is almost impossible for the competent authorities to detect this type of criminal activities.

- With regard to the effects of the crime of money laundering, it has been found that the crime has negative effects on the economic, political and social structure of any community if this criminal activity emerges, and the researcher believes that money laundering can become a long-term solution to demolish Any of the above-mentioned areas if the State tolerates this dangerous criminal activity.

- With regard to the nature of criminal responsibility for the crime of laundering, it has been found that money-laundering activity is a stand-alone crime. No legal provision dealing with another crime can comprehend the nature of this activity, whether in substantive or procedural terms, Which showed that the attempt to include money laundering 
activity under traditional criminal descriptions as an attempt to count them as a collateral contribution or a crime of concealment leads to the impunity of the perpetrators of money laundering crimes. The two descriptions are not compatible with washing duties the nature of its activity and its technical aspects, although these legal texts are of the capacity and flexibility that can be tempted to apply to the crime of money laundering. This has led the penal legislator in many countries to issue special laws or special legal texts to criminalize this activity on Despite the fact that these countries are not free of penal laws of legal provisions criminalize concealment and contributory contribution.

- With regard to the responsibility of the criminal bank for the crime of laundering money, it has been found that most of the criminal legislation that dealt with the crime of money laundering established criminal responsibility for banks and other legal persons that may have been involved in financial and banking activity, Money laundering activities. This legislation provided for a punishment commensurate with the nature of this legal person, such as fines, confiscation, closure of the legal person, and suspension from the exercise of his financial and banking work and his dissolution.

\section{Suggestions}

- Review the functional immunity exercised by the heads of departments in protecting their employees from accountability, where they exaggerate the protection of their employees, which is a stumbling block in efforts to combat corruption.

- Fighting poverty, this is one of the causes of corruption as a result of it, and strives to achieve social justice as much as possible.

- The development of educational and cultural curricula through the various media to create a culture of integrity and the preservation of public money through a long-term strategy, for the purpose of achieving loyalty and belonging between the individual and the state where the law is not the only deterrent to corruption, but must be here as a culture of integrity And save public money.

- Consolidate the three supervisory bodies, expand procedural and judicial powers, and review the previous laws of the Financial Control Bureau to take advantage of them in this regard.

- Maintain the independence of the regulatory body and make it away from quotas and sectarian and partisan influences, and activate the role of laws deterrent to corruption, financial and administrative.

- Intensify the training and development program of the regulatory body and to inform it of the best control experiences to combat corruption in all its forms and apply the experiences on the ground and not only the outflows outside the country with high demand without achieving real training and development in the performance of the regulatory body.

- Amend the immunity law granted to ministers and members of the House of Representatives to enable judicial authorities to investigate and prosecute corruption cases against them.

- Create public opinion that rejects corruption religiously and morally for its negative effects in the comprehensive economic development ie educating the community and gradual conversion of loyalty from the family and the clan to the nation and the state The fight against unemployment and inflation, described as disguised unemployment, by providing jobs and encouraging local investment And to prevent imports to stimulate national industry. 
- Establish effective and serious systems to evaluate the performance of government institutions through the principle of accounting for the costs of corruption, both physical and intangible, so as not to justify freezing the abolition of anti-corruption plans for the high costs of corruption costs.

- Promoting democracy and supporting good governance in order to prepare an integrated political system to face corruption and fight it through partisan pluralism and peaceful transfer of power. This will reduce the situation of the Palestinian people, so that everyone is subject to accountability and subject to change, the discovery of cases of administrative or financial corruption of the ruling power.

- The independence of the judiciary must be independent from political influences in order to ensure that judicial proceedings are conducted and that everyone is held accountable without exception, in a fair and fair manner.

- The role of the Parliament in its monitoring role and in order to achieve public interests and help the government to adjust its course and achieve its government program and not for partisan and partisan purposes or to catch mistakes only for political purposes.

- Civil society organizations have a prominent role in combating corruption. This is what the Bank's strategies in combating corruption emphasize. These organizations are a pressure factor on the government to make it more transparent and clear in its procedures, as well as monitoring corruption, Protecting poor classes and public money.

- To carry out institutional reforms by clarifying the work methods of government institutions and their procedures and supporting e-government systems in line with raising the efficiency of performance and providing the best services by easy and easy procedures for citizens and giving clarity so as not to exploit the complex procedures for the purposes of financial and administrative corruption.

- Use the administrative government and good governance of the institutions and involve the private sector to manage the economy and make it a competitor to the public sector or shared with him in order to reduce the burden on the government and rely on the private sector to manage some facilities capable, and this method ensures the provision of the best services and reduce corruption And eliminate bribery.

- All States that have not dealt with this crime shall initiate legislation to deal with the crime of moneylaundering, which is independent of the illicit activity, which is the source of the illicit funds to be laundering, The researcher believes that the Iraqi criminal legislator is one of the initiators of the criminalization of the money-laundering activity, which is an independent crime, and to determine to its perpetrators the criminal sanctions that are commensurate with the criminal legislative policy in Al-'Ara. S.

- Amend the laws, regulations and instructions reviewed by banks and financial institutions to ensure the establishment of a mechanism to detect illegal transactions and transactions and suspicious operations in line with sophisticated and modern methods that can be used by the perpetrators of the crime of washing and in front of these The mechanisms are related to the imposition of obligations on banks and financial institutions not to open bank accounts until after verifying the identity of the client, using documents and official documents proving the customer's personality, the nature of the activity carried out by the client, if 
possible, Customers and financial transactions made and other other obligations, which can help in the detection of financial transactions and suspicious transactions.

- Created supervisory bodies which are renowned for their expertise and efficiency in the business, financial and banking studies people working take on the supervision of banks, financial institutions and see the work when needed on customers' financial records related thereto and which are kept from bank accounts Such supervisory bodies shall have broad powers that go beyond the principle of bank secrecy, which shall be determined by virtue of an internal by-laws established by the competent authorities.

- Work on creating coordination between the legal rules of the subject of review by the banks in its work, particularly with regard to banking secrecy and methods of modern technology in the provision of banking services and the legal provisions relating to the criminalization of money laundering activity and in a form that does not The client or the financial institution shall be prohibited from using these services, and shall not be an obstacle in the face of the efforts of the competent authorities to combat money laundering activity on the other hand.

- Preparation of training courses for employees of banks and financial institutions, which are aimed at developing the administrative thought of the banking officer and improving the banking organization and removing ambiguity about the nature of banking work.

\section{References}

1. Dr. Abdulra'ouf Mahdi, Criminal Responsibility for Economic Crimes, Al-Ma'aref Establishment, Alexandria, Egypt, 1976.

2. Abdulqader Abdulhafez Al-Sheikhly, Arab and international efforts and agreements to combat economic crime, Naif Arab University for Security Sciences, Riyadh, Saudi Arabia, 2007.

3. Dr. Abdulhamid Al-Shawarbi, Financial and Commercial Crimes, University Publications House, Alexandria, Egypt, 1986.

4. Ahmed Anwar, The Social Effects of Economic Globalization, AL-A'ilah Library, Cairo, Egypt, 2004.

5. Ahmed Hussein Al-Hiti et al., The Phenomenon of the Hidden Economy and Money Laundering: Sources and Implications, Journal of Administration and Economics, No. (81), Baghdad, Iraq, 2010.

6. Basil Abdullatif Mohammed, Criminal Responsibility of Moral Persons: Comparative Study, Unpublished Master Thesis, College of Law and Politics, University of Baghdad, Baghdad, Iraq, 1978.

7. Emad Saeed Ali, Criminal Liability of the Legal Entities of the Penal Code (111) for the year 1969, research presented to the Judicial Institute, Baghdad, Iraq, 1985.

8. Dr. Huda Hamid Qashqoush, The crime of money laundering under international law, Dar Al-Nahdha AlArabiya, Cairo, Egypt, 1998.

9. Dr. Ibrahim Eid Nayel, Criminal Confrontation of the Money Laundering Phenomenon, First Edition, Arab Renaissance House, Cairo, Egypt, 1999.

10. Latif Taha Mahmoud, The Responsibility of the Respondent for his Work Followed, Research presented to the Justice Council, Ministry of Justice, Baghdad, Iraq, no publication year.

11. Dr. Mahmoud Mahmoud Mustafa, Crimes of Exchange, Part II, second edition, Cairo University Press and University Book, Cairo, Egypt, 1979.

12. Dr. Mahmoud Mahmoud Mustafa, Economic Crimes in Comparative Law, Second Edition, Cairo University Press and University Writers, Cairo, 1979.

13. Mazin Zaer Al-Lami, Corruption between Transparency and Autocracy, Dania Press, First Edition, Baghdad, Iraq, 2007.

14. Meloud Bouakada, Economic and Financial Crimes and Ways to Confront them Internationally and nationally, Unpublished Master Thesis, Department of Business Administration, Khamis Maliana University, Ain AlDoubledi, Algeria, 2013/2014.

15. Michael Gillan, Administrative Deviance: Its Causes and Methods of Treatment, Journal of Management, Volume IV, Second Issue, Cairo, Egypt, October 1975.

16. Mohammed Abdel Wadood Abu Omar, Criminal Responsibility for Disclosure of the Banking Secret: Comparative Study, First Edition, Dar Wael Publishing and Advertising, Amman, Jordan, 1999.

17. Mohamed Fathi, Contemporary Criminology, Naif Arab University for Security Sciences, Riyadh, Saudi Arabia, 1999. 
18. Mokhtar Shabili, Combating International Economic and Financial Crime, Unpublished Master Thesis, University of Blida, Algeria, 2004.

19. Mufid Nayef Turki, Money Laundering in Criminal Law: Comparative Study, unpublished doctoral dissertation, College of Law, Al-Nahrain University, Baghdad, Iraq, 2002.

20. Muhammad Abu Zahr, Crime and Punishment in Islamic Law, Dar Al-Fikr, Beirut, Lebanon, 1999.

21. Ramzi Najib al-Qusous, Money Laundering: The Crime of the Age, Dar Wael Publishing, Amman, Jordan, 2002.

22. Dr. Tawfiq Al-Shawi, Lectures on Criminal Responsibility in Arab Legislation, Institute of High Arab Studies, League of Arab States, Cairo, Egypt, 1958.

23. Tawfiq Ibrahim Ayoub, The Responsibility of the Auditor in Banking Crimes, Research Presented to the Union of Arab Banks and the Arab Institute for Banking Studies, Amman, Jordan, 1990.

24. Tawfiq Shambour, Banking secrecy, research presented to the symposium organized by the Union of Arab Banks, Beirut, Lebanon, 1993.

i. Ahmed Anwar, The Social Effects of Economic Globalization, ALA'ilah Library, Cairo, Egypt, 2004, P.17.

ii. Mokhtar Shabili, Combating International Economic and Financial Crime, Unpublished Master Thesis, University of Blida, Algeria, 2004, P.14.

iii. Muhammad Abu Zahr, Crime and Punishment in Islamic Law, Dar Al-Fikr, Beirut, Lebanon, 1999, P.2.

iv. Mazin Zaer Al-Lami, Corruption between Transparency and Autocracy, Dania Press, First Edition, Baghdad, Iraq, 2007, P.52. v. Ibid. P.55.

vi. Abdulqader Abdulhafez Al-Sheikhly, Arab and international efforts and agreements to combat economic crime, Naif Arab University for Security Sciences, Riyadh, Saudi Arabia, 2007, P.2

vii. Meloud Bouakada, Economic and Financial Crimes and Ways to Confront them Internationally and nationally, Unpublished Master Thesis, Department of Business Administration, Khamis Maliana University, Ain Al-Doubledi, Algeria, 2013/2014, P.37.

viii. Michael Gillan, Administrative Deviance: Its Causes and Methods of Treatment, Journal of Management, Volume IV, Second Issue, Cairo, Egypt, October 1975, P.212.

ix. Ahmed Hussein Al-Hiti et al., The Phenomenon of the Hidden Economy and Money Laundering: Sources and Implications, Journal of Administration and Economics, No. (81), Baghdad, Iraq, 2010, P.79.

x. Ibid. P.81.

xi. Abdulqader Abdulhafez Al-Sheikhly, Op.Cit., P.2 .

xii. Meloud Bouakada, Op.Cit. P.4.

xiii. Mohamed Fathi, Contemporary Criminology, Naif Arab University for Security Sciences, Riyadh, Saudi Arabia, 1999, P.279.

xiv. Wagray Cheryl, Corruption and Development, Journal of Finance, International Monetary Fund, March 1968, P.8.

$\mathrm{xv}$. The terms of criminal responsibility have evolved over different time periods. This development has been clearly reflected in the
25. Wagray Cheryl, Corruption and Development, Journal of Finance, International Monetary Fund, March 1968.

26. European Convention for the Protection of Human Rights and Fundamental Freedoms.

27. French Civil Law in Arabic, Saint Joseph University, Center for Juristic Studies of the Arab World, Beirut, Lebanon, 2012.

28. Iraqi Civil Code No. (40) Of (1951) amended.

29. Lebanese Banking Secrecy Act of (1956)

30. Law of the Central Bank of Iraq No. (64) Of (1976) Amended.

31. The Secrecy of Egyptian Banking Accounts No. (205) Of (1990).

32. Libyan Law No. (1) Of (1993) Concerning Banking, Cash and Credit Affairs.

33. Jordanian Banking Law No. (28) Of (2000).

34. https://www.echr.coe.int/Documents/Convention_ARA.pdf

\section{Footnote}

transition from the theory of material liability (responsibility for the consequences of the act) to personal responsibility (responsibility for error). This latter theory has stabilized in most of the world criminal systems.

The system (Anglo-American, Latinian or socialist) requires that the liability be erroneous on the one hand, and that the wrongdoer must have intellectual property that operates in a relatively sound manner.

For More Detail See: Dr. Tawfiq Al-Shawi, Lectures on Criminal Responsibility in Arab Legislation, Institute of High Arab Studies, League of Arab States, Cairo, Egypt, 1958, PP.21-22.

Dr. Abdulra'ouf Mahdi, Criminal Responsibility for Economic Crimes, Al-Ma'aref Establishment, Alexandria, Egypt, 1976, PP.16-18.

xvi. The process of attribution is not the only step to the application of the sentence, but to its side there are other steps related to determining the extent of the responsibility of the person responsible for the crime for the penalty. The assignment in the context of the economic crime has the specificity of determining the perpetrator of the crime and the person responsible for the crime. Rather, it is necessary to look at the originator of the crime. In fact, attribution is the true link between the perpetrator and the wrong, and this is to be supported by defining the law when the law establishes a person who bears criminal responsibility for the crime, but the perpetrator of the criminal act. When the law defines a person in charge of name or function and may be implied when the law does not expressly express its will, it is logical to conclude from the same system. The bank, through which money laundering operations are conducted, The person responsible for this crime is the bank's director when he is aware of the money that is being washed alone, and the attribution may be judicially within the discretion of the judge.

For More Detail See: Dr. Abdulra'ouf Mahdi, Op.Cit. PP.357-358. 
xvii. Dr. Mahmoud Mahmoud Mustafa, Crimes of Exchange, Part II, second edition, Cairo University Press and University Book, Cairo, Egypt, 1979, P.87.

xviii. Dr. Mahmoud Mahmoud Mustafa, Economic Crimes in Comparative Law, Second Edition, Cairo University Press and University Writers, Cairo, 1979, PP.135-136.

xix. The first paragraph of "Article (219) of the Iraqi Civil Code No. (40) OF (1951) Amended" states: "The government, municipalities and other institutions that serve the public and every person exploiting one of the industrial and commercial institutions are responsible for the damage Caused by their employees if the damage is caused by the loss of them while serving them."

For More Detail See: Latif Taha Mahmoud, The Responsibility of the Respondent for his Work Followed, Research presented to the Justice Council, Ministry of Justice, Baghdad, Iraq, no publication year, P.49.

xx. Basil Abdullatif Mohammed, Criminal Responsibility of Moral Persons: Comparative Study, Unpublished Master Thesis, College of Law and Politics, University of Baghdad, Baghdad, Iraq, 1978, PP.180-181.

xxi. Emad Saeed Ali, Criminal Liability of the Legal Entities of the Penal Code (111) for the year 1969, research presented to the Judicial Institute, Baghdad, Iraq, 1985, PP.22-26

xxii. Stefani (Gaston), L. Evasseur (Georges) et Bouloc (Bernord): Droit Penal general, 16 edition, Dalloz, 1997, P.253.

xxiii. Dr. Abdulhamid Al-Shawarbi, Financial and Commercial Crimes, University Publications House, Alexandria, Egypt, 1986, P.274.

xxiv. The term "Illegal Practices" in banking is a violation of government laws and regulations by the audited bank, its management or employees on its behalf and does not involve individual misconduct on the part of a member of the bank that is not related to the business and activity of the bank.

For More Detail See: Tawfiq Ibrahim Ayoub, The Responsibility of the Auditor in Banking Crimes, Research Presented to the Union of Arab Banks and the Arab Institute for Banking Studies, Amman, Jordan, 1990, P.58.

xxv. In (1989), the members of the Council of the major industrialized countries met in Paris a "Financial Action Task Force, FATF" called "FATF" to counter the phenomenon of money laundering. This group joined other countries so that their number after six years of composition is more than (26) State.

For More Detail See: Dr. Ibrahim Eid Nayel, Criminal Confrontation of the Money Laundering Phenomenon, First Edition, Arab Renaissance House, Cairo, Egypt, 1999.

xxvi. It should be noted that the international criminal legislator has taken great care in regard to the subject of criminal liability of the bank and financial institutions for the crime of money laundering, as evidenced by the international legislator's penalties commensurate with the nature of the moral character of the bank and financial institutions in the 40 recommendations or the
Convention Vienna or the United Nations Model Law on the crime of money-laundering.

For More Detail See: Dr. Huda Hamid Qashqoush, The crime of money laundering under international law, Dar Al-Nahdha AlArabiya, Cairo, Egypt, 1998, PP.76-78

xxvii. The criminal accountability of the bank for the crime of money laundering can be adapted as a criminal liability for the acts of others of exceptional nature. Without determining the accountability of banks and financial institutions for the criminal offense of money laundering, this will open the door wide for these banks and institutions to escape impunity.

For More Detail See: Dr. Huda Hamid Qashqoush, Op.Cit. P.78.

xxviii. Criminal jurisprudence defines the principle of bank secrecy as "the obligation of bank employees to maintain the secrets of their clients and not to disclose to others as the bank is entrusted by virtue of his profession, especially the relationship of the bank with its customers based on the confidence of the bank's secret secrets of its financial agents.

For More Detail See: Mohammed Abdel Wadood Abu Omar, Criminal Responsibility for Disclosure of the Banking Secret: Comparative Study, First Edition, Dar Wael Publishing and Advertising, Amman, Jordan, 1999, p.24.

xxix. This principle derives from Article 9 of the French Civil Code, which stipulates that: "Everyone has the right to the fulfillment of his or her private life".

And: Article (8) of "The European Convention for the Protection of Human Rights and Fundamental Freedoms".

For More Detail See: French Civil Law in Arabic, Saint Joseph University, Center for Juristic Studies of the Arab World, Beirut, Lebanon, 2012, P.247.

https://www.echr.coe.int/Documents/Convention_ARA.pdf, Last Visited: (12.07.2019), (13:46).

And also: Tawfiq Shambour, Banking secrecy, research presented to the symposium organized by the Union of Arab Banks, Beirut, Lebanon, 1993, P.68.

xxx. Tawfiq Shambour, Op.Cit. P.69.

xxxi. Mufid Nayef Turki, Money Laundering in Criminal Law: Comparative Study, unpublished doctoral dissertation, College of Law, Al-Nahrain University, Baghdad, Iraq, 2002, P.176.

xxxii. It should be noted that most of the laws under review and consideration of banking institutions have addressed the issue of bank secrecy and punished the violation of the principle of importance and this is what was taken by the Iraqi legislator in the second paragraph of Article (46) of the "Law of the Central Bank of Iraq No. (64) Of (1976) Amended", Article (46) of the "Jordanian Banking Law No. (28) Of (2000)" and the Libyan legislator in Article (73) of "Libyan Law No. (1) Of (1993) Concerning Banking, Cash and Credit Affairs".

While in some countries legislators have enacted a special law on banking secrecy for its importance, and this is what the Lebanese legislator did in the "Banking Secrecy Law of (1956) and the Egyptian legislator in the "Secrecy of Bank Accounts No. (205) Of (1990).

xxxiii. Ramzi Najib al-Qusous, Money Laundering: The Crime of the Age, Dar Wael Publishing, Amman, Jordan, 2002, P.88. 